\title{
Inflation Targeting in Iran
}

\author{
Bijan Bidabad $^{1} \quad$ Nahid Kalbasi Anaraki ${ }^{2}$
}

\begin{abstract}
Inflation targeting in various forms has been adopted by a number of countries as a framework for making monetary policy more coherent and transparent and for increasing the credibility of monetary policy. Despite the language, referring to inflation target as the primary objective of monetary policy, central bankers always make room for short-run stabilization objectives, particularly with respect to output and exchange rate. Inflation targeting, in most cases, reduces the role of intermediate targets, such as exchange rate or money growth rate.

Experience of other countries that have adopted inflation targeting as a monetary framework reveals that the success of the policy depends on not only the transparency of the operation but also on the budgetary discipline. Indeed, the central banks that have become more transparent, more independent, more coherent, and more accountable and more credible have been more successful.

The controversy among economists on the expenses of inflation targeting has attained particular attention during the past decades. While opponents believe that inflation targeting takes place at the expense of output shortfalls (Cechetti and Ehrmann 1999), proponents (Mishkin 2000, Jonas and Mishkin 2003) believe that inflation targeting promotes investment and economic growth. This paper tries to address the question of whether the performance of inflation targeting in Iran has been successful. Based on a monetary model, using exogenous variables such as official exchange rate, budget deficit, foreign exchange obligation account, and balance of payments, the results suggest that the effects of inflation targeting on the real output is trivial, supporting the natural rate hypothesis.
\end{abstract}

Keywords: Inflation Targeting, Macro-Econometric Model, Monetary Policy

\section{Introduction}

Indeed, the unhappy experience of the Latin America and East Asian countries with pegged exchange rate regimes who subsequently found themselves in deep financial crisis in the late 1990s has induced other countries to search for alternative nominal anchors. The emergence of inflation targeting over the past decade has been seen as a development in the approach of central banks to the conduct of monetary policy. After the adoption by New Zealand in 1990, inflation targeting has been the choice of a growing number of central banks in industrial and emerging economies, including Canada, Brazil, Chile, the Czech Republic, Poland, Sweden, and the U.K.

Inflation targeting is a monetary policy strategy that encompasses five main elements: (i) the public announcement of the medium-term numerical target for inflation (ii) an institutional commitment for price stability (iii) an information inclusive strategy in which, many variables, and not just monetary aggregates or the exchange rate are used for deciding the set of policy instruments (iv) increased transparency of the monetary policy strategy through communication with the public and the markets about the objectives, and decisions, (v) increased accountability of the central bank for attaining its inflation objectives.

Inflation targeting proponents cite many benefits to this policy, including solving the dynamic inconsistency problem that produces a high inflation rate and reducing inflation variability. Inflation targeting has also the key advantage that is easily understood by the public and thus is highly transparent. And last but not least, if flexible, it helps to stabilize output as well.

\footnotetext{
${ }^{1}$ (B.A., M.Sc., Ph.D., Post-Doc.) Research Professor of Economics, Monetary and Banking Research Academy, bidabad@yahoo.com bijan@bidabad.com http://www.bidabad.com .

${ }^{2}$ Nahid Kalbasi Anaraki, Faculty Member, Monetary and Banking Research Academy, E-mail: nkalbasi@aol.com
} 
Critics of inflation targeting have noted major disadvantages: (i) inflation targeting is too rigid (ii) it allows too much discretion (iii) it has the potential to increase output instability (iv) it will lower economic growth (v) it produces weak central bank accountability because inflation is hard to control and because there are long lags from the monetary policy instruments to the inflation outcome (vi) exchange rate flexibility required by inflation targeting might cause financial instability, (vii) and finally, it may not be sufficient to ensure fiscal discipline or prevent fiscal dominance.

Indeed, a relatively long list of requirements should be met if the inflation targeting is to operate successfully. These requirements include: (i) a strong fiscal position (ii) a well understood transmission mechanism between monetary policy instruments and inflation (iii) a well developed financial system (iv) a clear mandate for price stability (v) absence of other nominal anchors than inflation (vi) transparency and accountability of monetary policy. Indeed, it is not possible to say whether a country meets these requirements or not: it is more a question of the degree to which these preconditions are met.

One decade of inflation targeting in the world offers useful lessons on the design and implementation of this framework. Since the Iranian economy has started to adopt inflation targets in the medium-term through the Five Year Development Plans since 1989, this paper tries to investigate the feasibility of the targets within a monetary model. Moreover, it tests the hypothesis a trade-off between inflation targeting and real output.

In the next section, we review the performance of countries that have adopted inflation targeting. Section III is allocated to the inflation targeting and monetary policy instruments in Iran. Section IV presents the estimated results of a monetary model, measuring the trade-off between inflation and real output. And finally, the last section rap up and concludes.

\section{Experience of other countries}

In this section, we try to investigate the success of reducing inflation in some countries which adopted this policy. Moreover, we will investigate whether the reduction in inflation rate has occurred at the cost of real output reduction.

Cechetti and Ehrmann (1999) chose 23 countries where 9 have performed some targeting for reducing inflation. They show that for the latter group inflation fell by more than 7 percentage points on average, from 10.82 percent in the late 1980 s to 3.41 percent in the late 1990s, whereas for the non-targeted the average reduction amounts to 3.6 percent. Indeed, inflation targeting has achieved its primary objective of lowering inflation. Moreover, the output and inflation statistics support the view that inflation targeters have reduced inflation at the expense of an increase in output volatility. Indeed, the outcome depends on many issues, including a country's economic structure, its policy regime, and the actual pattern of shocks it has faced. ${ }^{3}$

In another study, Frederic S. Mishkin (2000) investigates inflation targeting in an emerging economy, Chile. Before embarking the inflation targeting, passed new central bank legislation in 1989, which gave independence to the central bank and mandated price stability as one of its primary objectives. Chile's central bank pursued a very gradualist approach to lowering its inflation objectives. The Chilean experience was quite successful. Inflation fell from about $20 \%$ in 1991 to around $3.5 \%$ in 2000. Over the same period, output growth was very high, averaging more than 8 percent per year. Chile experienced that inflation targeting can be used as a successful strategy for gradual disinflation in emerging market countries, even when initial inflation is around $20 \%$. It is important to notice that inflation targeting cannot be solely attributed to the actions of the central bank, supervision policies, such as the absence of fiscal deficits and supervision of the financial sector have been crucial to its success.

Jonas and Mishkin (2003) in their paper "Inflation Targeting in Transition Countries: Experiences and Prospects" examine the inflation targeting experience in three transition economies of the Czech Republic, Poland, and Hungary. A key lesson from the experience of inflation targeting in transition countries is that their economic performance has been improved. All these countries have an independent central bank with a clear mandate to pursue price stability. There has also been significant progress in making more transparent monetary policy decision and more accountable central banks. Financial markets are relatively well developed, allowing for reasonably effective transmission mechanism between monetary policy instruments and inflation.

With respect to fiscal position, fiscal deficits have widened significantly, particularly in the Czech Republic and Hungary. However, these deficits have not yet posed direct problems to inflation targeting in the sense of fiscal

3 -Cecchetti S. And M. Ehrmann "Does inflation targeting increase output volatility? An international comparison of policy makers' preferences and outcomes", NBER working paper 7426, Dec 1999. 
dominance of monetary policy because they have been financed by non-monetary means. Moreover, these countries have a regime of managed float, and inflation is the only nominal anchor in the economy. The experience of these transition countries shows that all three countries are preceding well with disinflation and there is a good chance that in a few years, they should be able to reach price stability. However, the process of disinflation is not a smooth one. In this respect, one should bear in mind that countries could be quite successful in the longer term in bringing inflation down, but if a successful disinflation is accompanied by significant instability of inflation, this could be costly for the economy as well.

There is not yet much we can say about the history of inflation targeting in Hungary because it is so recent. The 2001 target was announced only in August 2001, and it, therefore, was more a short-term inflation forecast than an actual inflation target. Table (1) presents the history of inflation targeting in the Czech Republic and Poland, telling a different story.

As it is seen in the above Table, in the Czech Republic, the central bank undershot her inflation target, particularly in 1998 and 1999. Only in 2001 the central bank succeeded in achieving her inflation targeting but undershot its target again in 2002. In Poland, there was an opposite problem since the national bank of Poland (NBP) overshot her target in 1999 and 2000. Very tight monetary policy and slowing economic activity helped to bring inflation down sharply in 2001, and subsequently, the 2001 and 2002 targets were undershot quite sizable. These deviations may seem to suggest that inflation targeting was not very successful in the Czech Republic and Poland.

Table (1). Targeted and actual inflation in the Czech Republic and Poland

\begin{tabular}{ccccc}
\hline Country & Czech Republic (inf) & Czech Republic (inf) & Poland (inf) & Poland (inf) \\
\hline Year & Target & Actual & Target & Actual \\
\hline 1998 & $5.5-6.5$ & 1.7 & X & 8.6 \\
\hline 1999 & $4-5$ & 1.5 & $6.4-7.8$ & 9.8 \\
\hline 2000 & $3.5-5.5$ & 3 & $5.4-6.8$ & 8.5 \\
\hline 2001 & $2-4$ & 2.4 & $6-8$ & 3.6 \\
\hline 2002 & $2.75-4.75$ & 0.5 & $4-6$ & 0.8 \\
\hline
\end{tabular}

Source: Jonas and Mishkin, "Inflation Targeting in Transition Countries: Experience and Prospects", NBER, working paper 9667, April 2003, p23.

Before making any definitive judgment about the success or failure of inflation targeting, it is important to understand the reasons for such significant deviations from targeted inflation. We have to examine more closely the domestic and external economic circumstances that have prevailed during this period and have affected the actual inflation. At the time that Czech central bank launched inflation targeting, inflation was rising quite rapidly, but at the same time, the economy was slipping into a prolonged recession. The 1998 and 2000 targets were specified at that time when the central bank, public and private forecasters expected much stronger economic growth than what actually occurred. However, in 1998-99 with the onset of a major banking crisis in 1997-98, economic activity fell down and contributed to a much faster disinflation than envisaged by the central bank. Moreover, in 1997-98, weak global economic activity contributed to falling commodity prices, including energy prices. The central bank calculations suggest that these external factors had a sizeable effect on net inflation; for instance, in 1998, these factors reduced the inflation by $2-3$ percentage points.

Like in the Czech Republic, inflation in Poland had declined significantly during 1998 and 1999, but this decline was less dramatic. The relatively rapid economic growth of domestic demand, increase in import prices, and monopolistic structure of some industries resulted in a reversal of disinflation in Poland in 1999. Fiscal policy was also much more expansionary than the national bank of Poland (NBP) had expected, and this expansionary stance further fueled domestic demand. The NBP responded to these developments by significant tightening of the monetary policy, and it continued to keep monetary conditions very tight even when inflation began to fall sharply later in 2000 and 2001. Indeed, the NBP tried to use a tight monetary policy stance as an instrument to force the government to strengthen the structural fiscal balance, even at the cost of significant undershooting of its inflation target.

Judging from the success point of view in meeting its inflation target, the NBP has not been very successful, thus far. In the first two years, inflation targets were overshot, and in the third and fourth years, there was a significant undershooting. Indeed, in Poland, external factors may have been of less importance in explaining the failure to meet inflation targets than in the Czech Republic, while the conduct of macroeconomic policy has probably mattered more. 
First, unexpected fiscal expansion combined with easy monetary policy contributed to the acceleration of inflation and overshooting of inflation targets; and subsequently, sharp tightening of monetary policy, in the absence of further easing of fiscal policy, reduced inflation sharply and produced a significant undershooting of the target. A difficult problem for inflation targeting in transition countries is the stormy relationship between the central bank and the government. This can be alleviated by having a direct government involvement in the setting of the inflation target and with a more active role of the central bank in communicating with both the government and the public.

Table (2). CPI Inflation Rates in Canada, New Zealand, Sweden, and the U.K.

\begin{tabular}{cccccc}
\hline Year & Canada & New Zealand & Sweden & The U.K. & Industrial countries \\
\hline $1977-1986$ & 7.5 & 13.1 & 9.2 & 9.5 & 7.3 \\
\hline 1987 & 4.4 & 15.7 & 4.2 & 4.1 & 3.1 \\
\hline 1988 & 4.0 & 6.4 & 5.8 & 4.9 & 3.4 \\
\hline 1989 & 5.0 & 5.7 & 6.4 & 7.8 & 5.4 \\
\hline 1990 & 4.8 & 6.1 & 10.5 & 9.5 & 4.5 \\
\hline 1991 & 5.6 & 2.6 & 9.3 & 5.9 & 3.3 \\
\hline 1992 & 1.5 & 1.0 & 2.3 & 3.7 & 3.0 \\
\hline 1993 & 1.8 & 1.3 & 4.6 & 1.6 & 2.4 \\
\hline 1994 & 0.2 & 1.7 & 2.2 & 2.5 & 2.6 \\
\hline 1995 & 2.1 & 3.7 & 2.5 & 3.4 & 2.4 \\
\hline 1996 & 1.6 & 2.3 & 0.5 & 2.4 & 2.1 \\
\hline 1997 & 1.5 & 1.1 & 0.5 & 3.2 & 1.5 \\
\hline 1998 & 0.9 & 1.2 & -0.1 & 3.4 & 1.4 \\
\hline 1999 & 1.7 & -0.1 & 0.4 & 1.5 & 2.2 \\
\hline 2000 & 2.7 & 2.5 & 0.9 & 2.8 & 2.2 \\
\hline 2001 & 2.5 & 2.7 & 2.4 & 1.8 & 1.5
\end{tabular}

Source: IMF, International Financial Statistics and IMF Outlooks,

Following McCallum (1996), we investigate inflation targeting arrangements in Canada, New Zealand, Sweden, and the United Kingdom, all of which adopted inflation targets between 1990 and 1993. A striking feature of the four arrangements is the similarity of the feedback procedures used by the central banks of these nations. In all of them, money market conditions were tightened or loosened when inflation forecasts for a year ahead lie outside the target range, whose width is 2 percent. To address the question of whether the performance of these countries has been successful, CPI inflation rates are reported in Table (2). For comparison, average CPI inflation rates across industrialized nations are reported in the final row.

As it is seen in Table (2) over the reported years prior to 1990, the four countries all had inflation rates that were higher than the average. In contrast, during 1992, 1993, and 1994, three of these countries experienced less inflation than the average of industrial countries. Whether or not, this outcome is a result of inflation targeting schemes per se; it would seem to be the case that the monetary policy stance has altered in these four countries. Moreover, as it is seen in the above-mentioned Table, the inflation rate has been lower than the average of industrial countries from 1994 to 1999 in four countries, except for the U.K. and for New Zealand in 1995, supporting the success of inflation targeting strategy.

Table (3) reports the real GDP growth rates for the four inflation targeting countries and the average value for the industrial countries. In these figures, one can find that undesirable real effects were generated by the adoption of antiinflationary measures. However, there has been an encouraging revival of growth since 1993, output growth rates above the industrial average were recorded in Canada, Sweden, and the United Kingdom. All in all, the results suggest that the four inflation targeters have experienced higher economic growth than the industrial average except for New Zealand in 1997 and 1998. 
Table (3). Real GDP Growth Rates in Canada, New Zealand, Sweden, and the U.K.

\begin{tabular}{cccccc}
\hline Year & Canada & New Zealand & Sweden & The U.K. & Industrial countries \\
\hline $1977-1986$ & 3.1 & 1.6 & 1.7 & 2.1 & 2.7 \\
\hline 1987 & 4.2 & -1.7 & 3.1 & 4.8 & 3.2 \\
\hline 1988 & 5.0 & 3.0 & 2.3 & 5.0 & 4.4 \\
\hline 1989 & 2.4 & -0.5 & 2.4 & 2.2 & 3.3 \\
\hline 1990 & -0.2 & -0.1 & 1.4 & 0.4 & 2.4 \\
\hline 1991 & -1.8 & -2.1 & -1.1 & -2.0 & 0.8 \\
\hline 1992 & 0.6 & -0.2 & -1.9 & -0.5 & 1.5 \\
\hline 1993 & 2.2 & 4.1 & -2.1 & 2.2 & 3.0 \\
\hline 1994 & 4.5 & 4.8 & 2.2 & 3.8 & 2.8 \\
\hline 1995 & 2.77 & 3.7 & 3.7 & 5.5 & 3 \\
\hline 1996 & 1.7 & 3.0 & 1.0 & 5.9 & 3.5 \\
\hline 1997 & 3.9 & 2.5 & 2.0 & 6.4 & 2.7 \\
\hline 1998 & 3.5 & -0.4 & 3.6 & 6.0 & 3.4 \\
\hline 1999 & 15.8 & 4.1 & 4.5 & 4.9 & 3.9 \\
\hline 2000 & 9.2 & 2.0 & 3.6 & 4.7 & 1 \\
\hline 2001 & 3.9 & 4.3 & 1.2 & 4.5 & 1.8 \\
\hline 2002 & 4.2 & - & 3.6 & 5.6 & \\
\hline
\end{tabular}

Source: IMF, International Financial Statistics, and IMF Outlook.

\section{Inflation Targeting in Iran}

Before implementing the First and Second Five Year Development Plan there is no record of inflation targeting in Iran, however, during the first two plans (1989-1994 and 1996-2001) inflation targets have been set within the plans. Though there are some similarities between inflation targeting in Iran and other countries, the targets stand at much higher levels in Iran compared with other countries. For instance, The Second Five Year Development Plan envisaged an inflation target of $12 \%$, and the Third Development Plan targeted an inflation rate of $15 \%$.

Indeed, to achieve the goals, monetary authorities need to implement all the monetary instruments effectively. However, in Iran, due to the lack of central bank independence and administrative, regulatory, monetary authorities have been being unable to use money market operations, discount rate, and the reserve requirement effectively. As a result, monetary authorities have not succeeded to achieve the goals, undermining the credibility of the policies.

The decomposition of the monetary base in Iran, since the revolution (1978), reveals that the government debt to central bank has adversely affected the effectiveness of monetary instruments. On the other hand, the monetary instruments have been limited through the Islamic Banking Law approved in 1982. Indeed, under current circumstances, the only means to control the money supply are through the reduction of government debt to the central bank and also increasing the reserve requirement ratio. The legal framework for controlling government debt has been envisaged in the five-year development plans and the budget laws. Accordingly, credit ceilings have been set with emphasize on the monetary authorities' responsibilities to react against any increase in the money supply.

Though the government deficit has been controlled according to the budget law and the plan, the foreign exchange obligation account ${ }^{4}$ increased enormously during the past decade. The government used this account to service its foreign debts with the official exchange rate, which has enlarged the money supply, in turn. The major challenge that the government faces with is the lack of fiscal discipline, which in turn, may lead to the failure of inflation targeting as a framework for monetary policy. Indeed, the dominance of the fiscal sector on the monetary authorities has undermined the independence of the central bank, leaving small room for the success of inflation targeting strategy.

As the credit ceilings are determined for a financial year within the budget, they should be allocated on a monthly basis and announced to the banks. In case, there is a violation from the credit ceiling it should be adjusted within the next month. To achieve this goal, the central bank needs to implement monetary instruments, forecast the monetary

\footnotetext{
${ }^{4}$ Foreign exchange obligation account was established in 1993 to compensate the importers for the difference of the unified exchange rate with the nominal exchange rate.
} 
aggregates, and find out the relationship between the general price level and the allocated credits. In doing so, the central bank needs a monetary model to evaluate the stance of monetary policy. Such a model will be presented in the next section to forecast the inflation rate and to evaluate the trade-off between inflation targeting and the real output.

Most of the empirical studies that have been carried out for Iran (Komijani and Bidabad 1999) suggest that the supply side factors or cost-push inflation have lower effects on the CPI inflation than demand-push factors. Indeed, according to the empirical studies, $99 \%$ of the changes in CPI, in the long run, can be explained by the money supply. In other words, these studies suggest that inflation in Iran is a monetary phenomenon. Therefore, the most appropriate way to control inflation is through money supply. Moreover, the monetary transmission mechanism of the real sector is trivial. Any change in the money supply has negligible effects on the interest rate and investment due to administered interest rates. All in all, one can argue that any decrease in the money supply will not affect the real sector of the economy in the long-run.

Concerning the monetary policy stance, it has historically been dominated by fiscal policy. Therefore, inflation targeting will be a more appropriate instrument to conduct the monetary policy with a consensus between the monetary authorities, government, and the public. Indeed, the pragmatic argument for inflation targeting begins with the proposition that, from a long-run point of view, monetary policy has a dominating influence on an economy's inflation rate and negligible influence on its rate of unemployment and output. This proposition, which is an interpretation of the natural rate hypothesis, is supported by the empirical results, as will be seen in the next section.

\section{Monetary model:}

The rationale for inflation targeting emerges as the joint consequences of two lines of thoughts within the economics of monetary policy. First, because the central bank in effect has only one instrument at its disposal, the standard Tinbergen-Theil logic implies that it is possible to express the policy chosen at any time in terms of the intended outcome of any single economic magnitude that monetary policy affects: inflation, output, employment, the economy's foreign balance.

The second line of thought within the field that underlies the concept of inflation targeting is the Phelps-Friedman "natural rate" model of aggregate supply in the market for goods and services. Under the most familiar version of the natural rate model, there exists a trade-off between real outcomes like output and employment and nominal outcomes like inflation and prices. By contrast, in the long run, there is no evidence to support such a trade-off; long-run real outcomes depend on such real factors as endowments, technologies, and etc. In the long run, nominal magnitudes are subject to monetary influences. Indeed, aggregate shocks that move output and inflation in opposite directions create a trade-off between output and inflation variability, forcing the central bankers to make a choice.

In this section, we present a very simple monetary model according to the monetarists' view. The following flow chart presents the relationship between the main variables of the model. As it is seen, the liquidity is decomposed to the net domestic assets and net foreign assets of the banking system. The net foreign asset component is affected by the official exchange rate and the balance of payments. The net domestic assets consist of three components: private sector debt to the banking system, government debt to the banking system, and net of other assets. The private sector debt to the banking system is affected by gross domestic product (GDP). The government debt to the banking system is influenced by the government budget deficit and foreign exchange obligations account. The price level is defined as a function of liquidity. Change in GDP is affected by the balance of payments. The estimated results are presented in the following section, and the econometric model is estimated by OLS technique. The sample period covers 1960-2001. To avoid integration problems, all level variables are used in their first differences.

\section{List of variables:-}

M2NFAE=Net foreign assets of the banking system (in billion dollars)

M2NGV=Net government debt to the banking system (in billion Rials)

M2LPV=Net Private sector debt to the banking system (in billion Rials)

$\mathrm{M} 2 \mathrm{NW}=$ Other assets of the banking system (in billion Rials)

$\mathrm{OBD}=$ Government budget deficit (in billion Rials) 
$\mathrm{BOP}=\mathrm{Balance}$ of payments (million dollars)

FEOA=Foreign exchange obligation account (in billion Rials)

GDPV=Nominal GDP (in billion Rials)

GDP=Gross Domestic Production at fixed prices of 1982 (in billion Rials)

PGDP $=$ GDP deflator $($ base year $=1982$ )

M2 = Liquidity (in billion Rials)

$\mathrm{E}=$ Exchange rate

D61 = Dummy variable, one for 1982 and zero otherwise

D69 = Dummy variable, one for 1990 and zero otherwise

D72 = Dummy variable, one for 1993 and zero otherwise

D5873=Dummy variable, one for 1994-95 and zero otherwise

$\mathrm{D}=$ Difference operator

$@$ Trend $=$ Time trend

The following system of equations was estimated.

$\mathrm{D}(\mathrm{M} 2 \mathrm{NFAE})=\mathrm{C}(11) * \mathrm{BOP} / 1000+\mathrm{C}(12) * \mathrm{D} 72+\mathrm{C}(13) * \mathrm{D} 69+\mathrm{C}(14) * \mathrm{D} 60+\mathrm{c}(15) * \mathrm{D} 7680$

$\mathrm{D}(\mathrm{M} 2 \mathrm{NGV})=\mathrm{C}(20)+\mathrm{C}(21) * \mathrm{OBD}+\mathrm{C}(22) * \mathrm{OL}+\mathrm{D}(\mathrm{FEOA})+\mathrm{C}(23) * \mathrm{D} 79+\mathrm{C}(24) * \mathrm{D} 80$

$\mathrm{D}(\mathrm{M} 2 \mathrm{LPV})=\mathrm{C}(31) * \mathrm{D}(\mathrm{GDPV})+\mathrm{C}(32) * \mathrm{D} 80$

$\mathrm{D}(\mathrm{M} 2 \mathrm{NW})=\mathrm{C}(41) * \mathrm{D} 7780+\mathrm{C}(42) * \mathrm{D} 79+\mathrm{C}(43) * \mathrm{D} 80+\mathrm{C}(44) * @ \mathrm{TREND}$

$\mathrm{D}(\mathrm{PGDP})=\mathrm{C}(51) * \mathrm{D}(\mathrm{M} 2)+\mathrm{C}(52) * \mathrm{D} 80$

$\mathrm{D}(\mathrm{GDP})=\mathrm{C}(60)+\mathrm{C}(61) * \mathrm{BOP} / 1000+\mathrm{C}(62) * \mathrm{D}(\mathrm{GDP}(-1))+\mathrm{C}(63) * \mathrm{D} 5659+\mathrm{C}(64) * \mathrm{D} 65+\mathrm{C}(65) * \mathrm{D} 55$

$\mathrm{M} 2=\mathrm{M} 2 \mathrm{NFAE} * \mathrm{E}+(\mathrm{M} 2 \mathrm{NGV}+\mathrm{M} 2 \mathrm{LPV}+\mathrm{M} 2 \mathrm{NW})$

GDPV $=$ GDP $*$ PGDP 
Flowchart (1). Relationship between the main variables of the monetary model

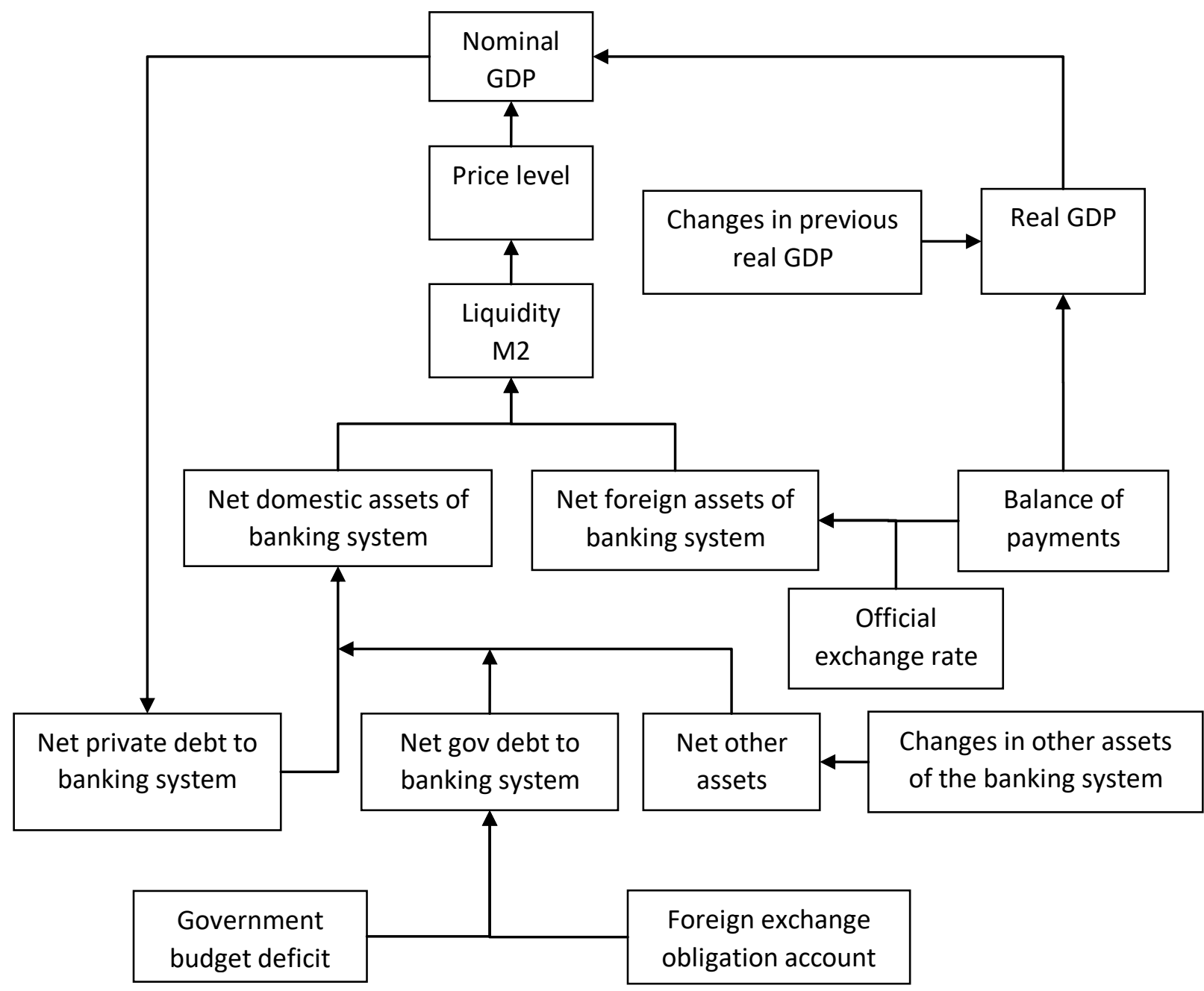

ニニニニニニニニニニニニニニニニニニニニニニニニニニニニニニニニニニニニニニニニニニニニニニニニニニニ

System: SYS_INF

Estimation Method: Least Squares

Sample: 13391380

Included observations: 42

Total system (unbalanced) observations 251

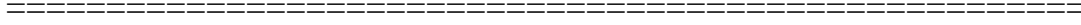

Coefficient Std. Error t-Statistic Prob.

\begin{tabular}{|c|c|c|c|}
\hline $\mathrm{C}(11)$ & 0.914673 & 0.097201 & 9.410124 \\
\hline $\mathrm{C}(12)$ & -21.40064 & 1.346235 & -15.89666 \\
\hline
\end{tabular}




\begin{tabular}{lrlll}
$\mathrm{C}(13)$ & 9.443943 & 1.346362 & 7.014414 & 0.0000 \\
$\mathrm{C}(14)$ & 5.263224 & 1.367823 & 3.847885 & 0.0002 \\
$\mathrm{C}(15)$ & -2.368778 & 0.621046 & -3.814173 & 0.0002 \\
$\mathrm{C}(20)$ & -274.1686 & 167.8247 & -1.633661 & 0.1037 \\
$\mathrm{C}(21)$ & 1.257852 & 0.055344 & 22.72777 & 0.0000 \\
$\mathrm{C}(22)$ & 0.219124 & 0.027767 & 7.891556 & 0.0000 \\
$\mathrm{C}(23)$ & -14060.40 & 975.8079 & -14.40899 & 0.0000 \\
$\mathrm{C}(24)$ & 11626.61 & 962.0447 & 12.08531 & 0.0000 \\
$\mathrm{C}(31)$ & 0.309446 & 0.012301 & 25.15634 & 0.0000 \\
$\mathrm{C}(32)$ & 33424.48 & 2846.179 & 11.74363 & 0.0000 \\
$\mathrm{C}(41)$ & -12933.99 & 598.0382 & -21.62736 & 0.0000 \\
$\mathrm{C}(42)$ & 29662.57 & 960.1021 & 30.89523 & 0.0000 \\
$\mathrm{C}(43)$ & 4877.350 & 960.1694 & 5.079677 & 0.0000 \\
$\mathrm{C}(44)$ & -15.28007 & 5.684013 & -2.688254 & 0.0077 \\
$\mathrm{C}(51)$ & $7.03 \mathrm{E}-06$ & $2.96 \mathrm{E}-07$ & 23.79357 & 0.0000 \\
$\mathrm{C}(52)$ & -0.294803 & 0.032899 & -8.960742 & 0.0000 \\
$\mathrm{C}(60)$ & 6249.474 & 1531.646 & 4.080234 & 0.0001 \\
$\mathrm{C}(61)$ & 1354.759 & 568.7077 & 2.382171 & 0.0180 \\
$\mathrm{C}(62)$ & 0.368434 & 0.093348 & 3.946897 & 0.0001 \\
$\mathrm{C}(63)$ & -23153.95 & 4256.940 & -5.439107 & 0.0000 \\
$\mathrm{C}(64)$ & -26557.75 & 8121.092 & -3.270219 & 0.0012 \\
$\mathrm{C}(65)$ & 23064.76 & 8199.437 & 2.812969 & 0.0053 \\
\hline & & & & \\
\hline
\end{tabular}

Determinant residual covariance 5.51E+22

Equation: $\mathrm{D}(\mathrm{M} 2 \mathrm{NFAE})=\mathrm{C}(11) * \mathrm{BOP} / 1000+\mathrm{C}(12) * \mathrm{D} 72+\mathrm{C}(13) * \mathrm{D} 69+\mathrm{C}(14) * \mathrm{D} 60+\mathrm{C}(15) * \mathrm{D} 7680$

Observations: 42

R-squared $\quad 0.913271$ Mean dependent var 0.132592

Adjusted R-squared $0.903895 \quad$ S.D. dependent var 4.341973

S.E. of regression $1.346047 \quad$ Sum squared resid 67.03814

Durbin-Watson stat 2.147208

Equation: $\mathrm{D}(\mathrm{M} 2 \mathrm{NGV})=\mathrm{C}(20)+\mathrm{C}(21) * \mathrm{OBD}+\mathrm{C}(22) * \mathrm{OL}+\mathrm{D}(\mathrm{FEOA})+\mathrm{C}(23) * \mathrm{D} 79+\mathrm{C}(24) * \mathrm{D} 80$

Observations: 42 
R-squared $\quad 0.971197$ Mean dependent var 2320.165

Adjusted R-squared 0.968084 S.D. dependent var 5260.589

S.E. of regression 939.8117 Sum squared resid 32680103

Durbin-Watson stat 2.238885

Equation: $\mathrm{D}(\mathrm{M} 2 \mathrm{LPV})=\mathrm{C}(31) * \mathrm{D}(\mathrm{GDPV})+\mathrm{C}(32) * \mathrm{D} 80$

Observations: 42

R-squared $\quad 0.960945$ Mean dependent var 5773.873

Adjusted R-squared 0.959969 S.D. dependent var 13071.46

S.E. of regression 2615.321 Sum squared resid 2.74E+08

Durbin-Watson stat 1.049681

Equation: $\mathrm{D}(\mathrm{M} 2 \mathrm{NW})=\mathrm{C}(41) * \mathrm{D} 7780+\mathrm{C}(42) * \mathrm{D} 79+\mathrm{C}(43) * \mathrm{D} 80+\mathrm{C}(44) * @ \mathrm{TREND}$

Observations: 42

R-squared $\quad 0.967070 \quad$ Mean dependent var-692.9867

Adjusted R-squared $0.964470 \quad$ S.D. dependent var 4158.716

S.E. of regression 783.8891 Sum squared resid 23350323

Durbin-Watson stat 3.436861

Equation: $\mathrm{D}(\mathrm{PGDP})=\mathrm{C}(51) * \mathrm{D}(\mathrm{M} 2)+\mathrm{C}(52) * \mathrm{D} 80$

Observations: 42

R-squared $\quad 0.923764$ Mean dependent var 0.047743

Adjusted R-squared 0.921858 S.D. dependent var 0.089887

S.E. of regression 0.025127 Sum squared resid 0.025254

Durbin-Watson stat 2.826425

Equation: $\mathrm{D}(\mathrm{GDP})=\mathrm{C}(60)+\mathrm{C}(61) * \mathrm{BOP} / 1000+\mathrm{C}(62) * \mathrm{D}(\mathrm{GDP}(-1))+\mathrm{C}(63) * \mathrm{D} 5659+\mathrm{C}(64) * \mathrm{D} 65+\mathrm{C}(65) * \mathrm{D} 55$

Observations: 41

R-squared $\quad 0.706315$ Mean dependent var 6893.122

Adjusted R-squared 0.664359 S.D. dependent var 13732.14

S.E. of regression 7955.646 Sum squared resid 2.22E+09

Durbin-Watson stat 1.521260 
Graph 1 Plot of residuals of estimated equations
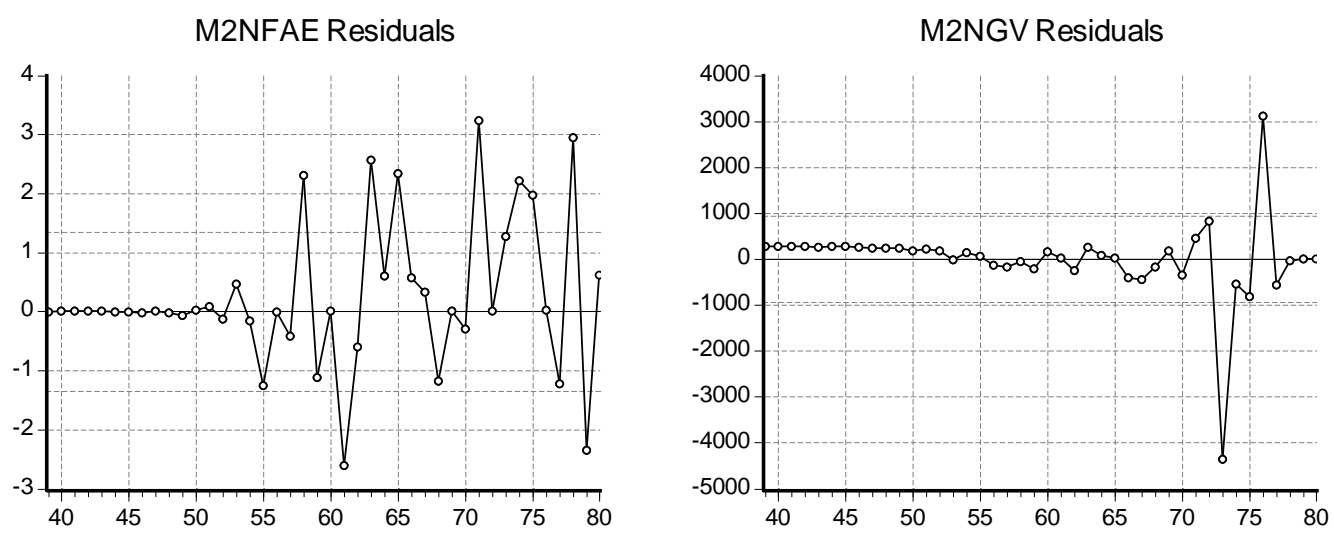

M2LPV Residuals
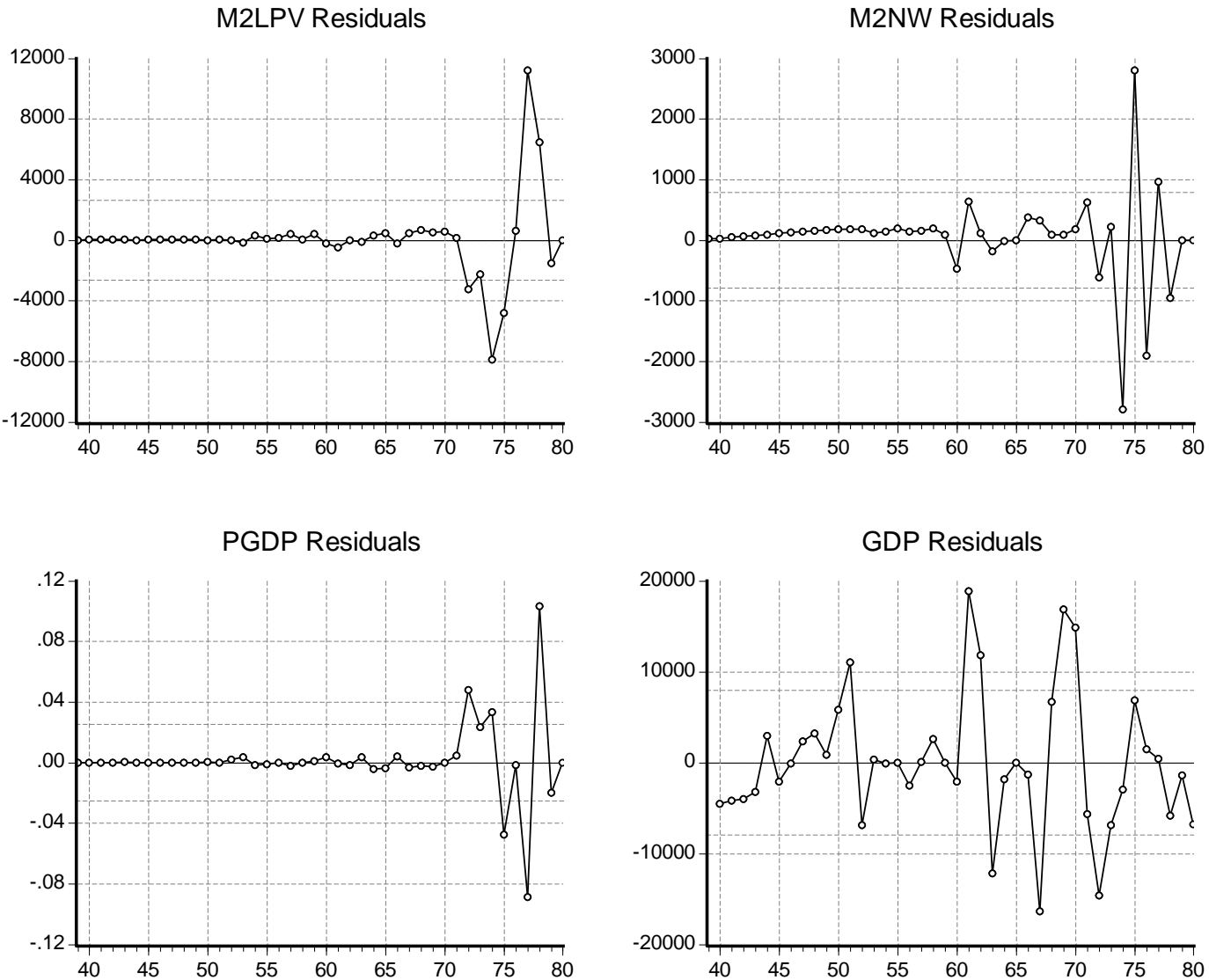

As it is seen in the estimated results, the net foreign assets of the banking system has a positive significant relationship with the balance of payments. The coefficient on $\mathrm{C}(21)$ is positive and significant, supporting a positive link between the government budget deficit and the government debt to the banking system. The coefficient on $\mathrm{C}(22)$ is also positive and significant, representing a relationship between the obligation loans and the government debt to the banking system. Interestingly enough, foreign exchange obligation account has a one to one relationship with the net government debt to the banking system. 
Equation (5) suggests that nominal GDP is positively and significantly related to the liquidity, supporting the monetarists' view. In other words, any change in the money supply will affect the nominal GDP. In addition, net private sector debt to the banking system is positively and significantly correlated with nominal GDP. Equation (6) suggests that real GDP at fixed prices is positively and significantly related to the BOP.

To evaluate the performance of the model, we solved the whole system for the whole ex-post sample period through dynamic simulation. Graph 2 plots the actual value of the endogenous variables versus their simulated values. The 8 plots of Graph 1 show the high dynamic response and credibility of the model to build simulated series as near as the actual series with a concordance of turning points.

Graph 2 Simulated versus actual values of the endogenous variables in the dynamic solution
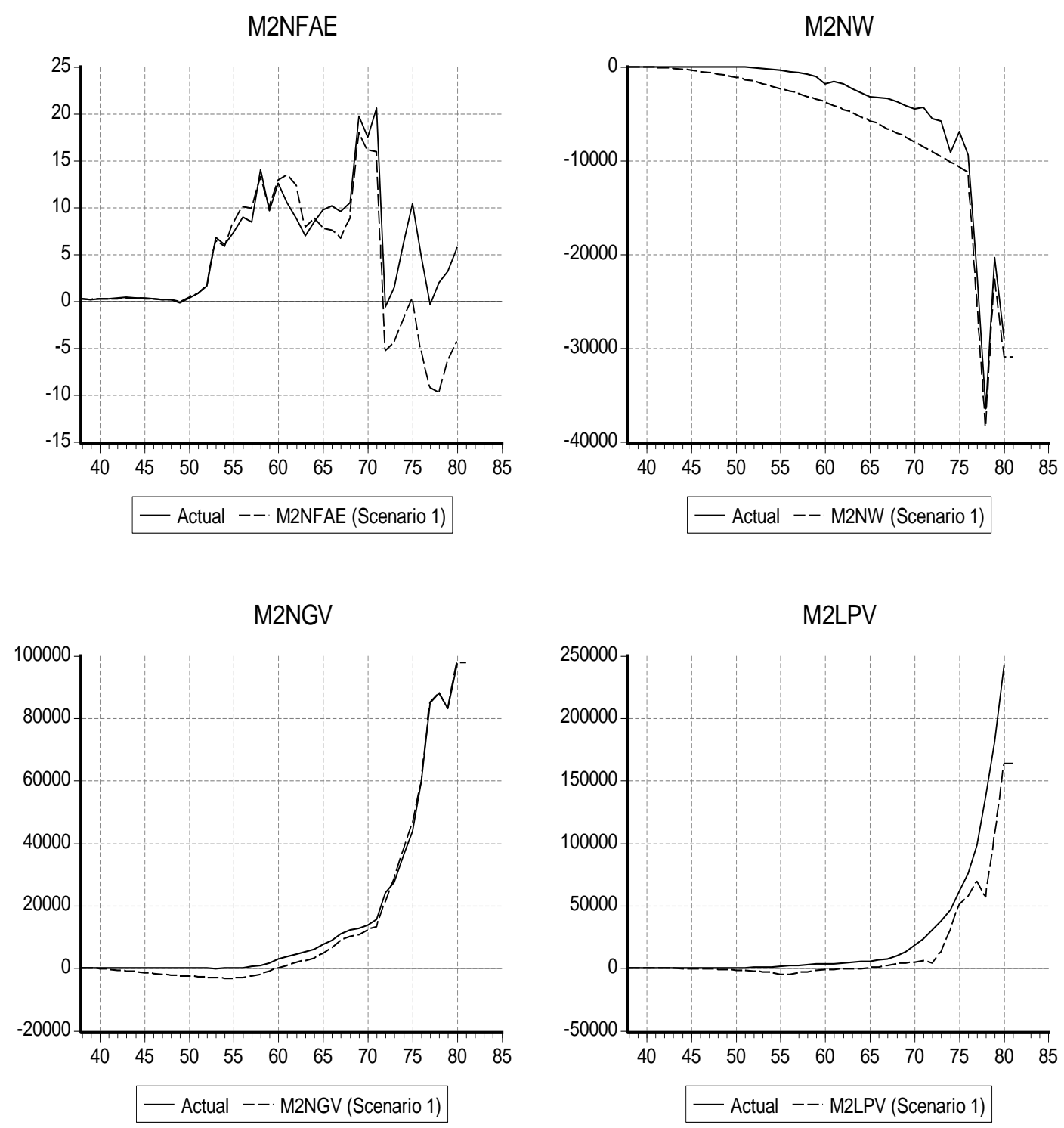
Graph 2 (Cont.) Simulated versus actual values of the endogenous variables in the dynamic solution
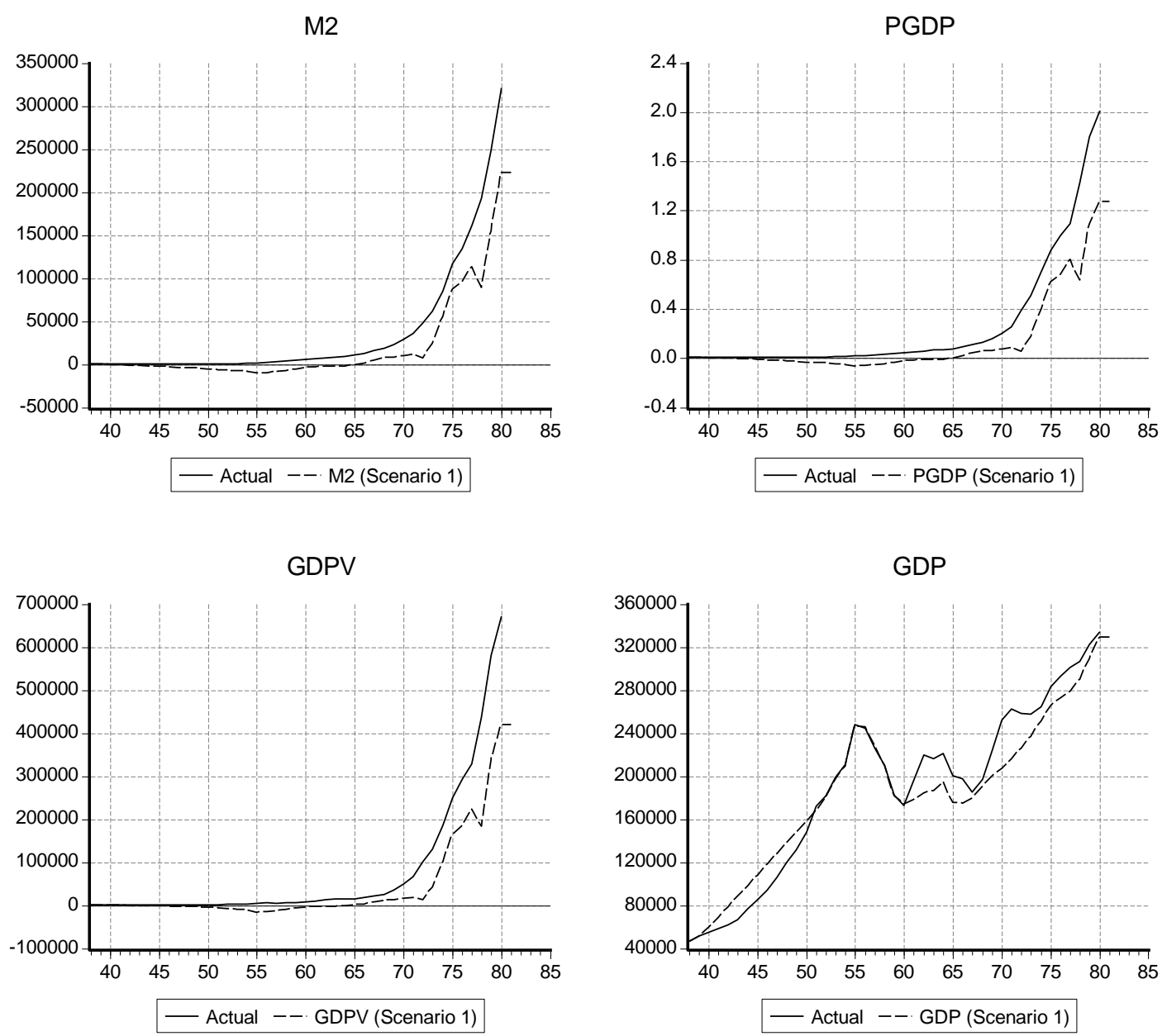

\section{Conclusion}

As the estimated results in the previous section suggest, inflation targeting in Iran does not affect the real output in the long run. Indeed, monetary transmission policy affects the general price level, leaving trivial effects on the real output. Therefore, one can argue that there is no trade-off between inflation targeting and the real output, supporting the notion of the natural rate hypothesis.

One of the main findings of this study is that major problem in achieving inflation targets in the Iranian economy is the lack of transparency and credibility of the target due to fiscal situation, institutional set up for the monetary policy, and ineffectiveness of monetary instruments. Indeed, as the experiences of other countries suggest fiscal discipline has a crucial role in the success of inflation targeting.

Moreover, the inflation target lacks credibility in Iran, in the sense that inflation expectations exceed the target range. Reduction of the real budget deficit through reducing the foreign exchange obligation account might restore the credibility of the government and monetary authorities.

Imperfect credibility has several detrimental consequences. First, imperfect credibility makes it more costly and more difficult to achieve the target. Monetary policy has to be more contractionary to counter the inflationary impulses that inflation expectation causes. 
Second, imperfect credibility most likely allows less scope for short-run stabilization of unemployment. Any attempt to temporarily pursue a more expansionary policy in order to reduce temporarily high unemployment will probably be interpreted as increased tolerance towards medium and long-run inflation, and hence induce a further fall in already low credibility, with increased inflation expectations and increased medium and long-term interest rates, as a result. The increased inflation expectation is also likely to result in faster nominal wage and price adjustment, which reduces the real effect of a given monetary expansion.

Indeed, the government and the parliament in their attempts to expand the credibility of the system should reduce their incentives to create inflation by strengthening price stability as a goal for monetary policy. In doing so, the government and the parliament can achieve fiscal consolidation by eliminating partial de-indexing of expenditures and taxes. The most crucial challenge that the central bank should overcome is to remedy the credibility problem through pursuing a monetary policy that fulfills the inflation targets. The central bank can increase its commitment by a policy statement that clarifies that inflation targets will be strictly in effect for the whole third plan.

\section{References}

Ball Laurence, and Niamh Sheridan, "Does Inflation Targeting Matter?" NBER, working paper 9577, March 2003.

Bernanke, B.S. and F.S. Mishkin," Inflation Targeting: A New Framework for Monetary Policy, Journal of Economic Perspectives, 1997.

Bernanke Ben S., Laubach, Thomas, Mishkin Fredric S. and Posen Adam S. " Inflation Targeting: Lessons from the International Experience. Princeton, NJ: Princeton University Press.

Bidabad, Bijan, General monetary equilibrium. Lap Lambert Academic Publishing, OmniScriptum GmbH \& Co. KG, ISBN: 978-3-659-54045-5, Spring 2014.

Bidabad, Bijan, Parallel Exchange Market Control by Monetary Targeting and Complementary Policies. Monetary and Banking Research Academy, Central Bank of Iran, Tehran, Iran, 2007. http://www.bidabad.com/doc/exchange-control.pdf

Bidabad, Bijan, Analysis of built models for appropriate monetary policy for economic stabilization in Iran, Parliament and Research, Journal of Research Center of Iran's Parliament, No. 9, $2^{\text {nd }}$ year, pp. 59-95, Tehran, Iran, 1994.

http://www.bidabad.com/doc/siyasathaye-pooli-banameh-dovom.pdf

Bidabad, Bijan, (2007) Triangular Causality and Controlling Parallel Exchange Market. Monetary and Banking Research Academy, Central Bank of Iran, Tehran, Iran. http://www.bidabad.com/

Bidabad, Bijan, M.J. Mojarrad, The inflation targeting policy for Iran. Proceeding of the $6^{\text {th }}$ conference of monetary and exchange rate policies, Monetary and Banking Research Academy, Central Bank of Iran, pp. 21-57, 1996. Some parts of it reprinted under the titles: "Price control by inflation targeting" and "Experience of some countries on inflation targeting policy"; Tazehaye Eghtesad, the monthly review of science, economic and banking, pp. 10-14. 22-27, no. 79, August 1999. Monetary and Banking Research Academy, Central Bank of Iran.

http://www.bidabad.com/doc/hadafgozari-tavarom.pdf

Cechetti S, and M. Ehrmann "Does Inflation Targeting Increase Output Volatility? An International Comparison of Policymakers preferences and Outcomes", Central Bank of Chile, working paper 69, April 2000. http://www.bcentral.c1/Estudios/DTBC/69/dtbc69.pdf

Cecchetti Stephen G. and Junhan Kim, "Inflation Targeting, Price-Path Targeting, and Output Variability", NBER working paper 9672, May 2003.

Christiano, Lawrence J., Martin Eichenbaum; Charles L. Evans, "Identification of the Effects of Monetary Policy Shocks," in M.I. Blejer et al. eds, Financial Factors in Economic Stabilization and Growth. New York, Cambridge University Press, 1996.

Ditmar R., Gavin, W.T, and F.E. kydland "What Do New-Keynesian Phillips Curves Imply for Price Level 
targeting, Review, Federal Reserve Bank of St. Louis 2000.

Estrella Arturo and Frederic S. Mishkin "Is There a Role for Monetary Aggregates in the Conduct of Monetary Policy", Journal of Monetary Economics, October 1997.

Feldstein, M. "The Costs and benefits of Price Stability", NBER working paper 6200, September 1997.

Friedman, Benjamin M., "The Use and Meaning of Words in Central Banking: Inflation Targeting, Credibility, and Transparency, NBER working paper 8972, June 2002.

Jonas. Jiri, and Frederic S. Mishkin "Inflation Targeting in Transition Countries: Experience and Prospects, NBER working paper 9667, April 2003.

King, M., "Challenges for Monetary Policy: New and Old", in New Challenges for Monetary Policy, Federal Reserve Bank of Kansas City, Kansas City, Missouri, 1999.

Komijani, A; Bijan Bidabad, Appropriate monetary policy for economic stabilization in Iran. Research project no. 111. Ministry of Finance and Economic Affairs, Deputy of Economic Affairs, Tehran, Iran, Phase I, 1992. Reprinted (book) by Deputy of Economic Affairs, Ministry of Finance and Economic Affairs, 1994. Reprinted in Economic Journal, Deputy of Economic Affairs, Ministry of Finance and Economic Affairs, vol. 4, pp. 2-14, vol. 5 pp. 2-12, vol. 6, pp. 2-9, vol. 7 pp. 2-7, 1996. http://www.bidabad.com/doc/siyasathayepooli-vol1.pdf

Komijani, A; Bijan Bidabad, Appropriate monetary and exchange rate policy for economic stabilization in Iran (emphasizing adjustment policies), Deputy of Economic Affairs, Ministry of Finance and Economic Affairs, Tehran, Iran, Phase II, 1993. Reprinted (book) by Deputy of Economic Affairs, Ministry of Finance and Economic Affairs, 1996.

http://www.bidabad.com/doc/siyasathaye-pooli-vol2.pdf

Masson Paul, R., Savastano, Miguel A.; Sharma Sunil. "The Scope for Inflation Targeting in Developing Countries, IMF working paper 130, October 1997.

McCallum Bennett T., "Inflation Targeting in Canada, New Zealand, Sweden, The United Kingdom, And In General", NBER working paper 5579, May 1996.

McCallum Bennett T., "Specification of Policy Rules and performance Measure in Multicountry Simulation Studies, Journal of International Money and Finance, June 1994.

Mishkin Frederic S., "Inflation Targeting in Emerging Market Countries", American Economic Review, May 2000.

Mishkin Frederic S., "Issues in Inflation Targeting "in Price Stability and the Long-run Target for Monetary Policy, Bank of Canada,: Ottawa, Canada, 2001.

Mishkin Frederic S. "International Experiences with Different Monetary Regimes", Journal of Monetary Economics, 43, 1999.

Mishkin Frederic S., "International Experiences With different Monetary Policy Regimes," Journal of Monetary Economics, Vol 43, 1999.

Mishkin Frederic S, and Posen, Adam S. "Inflation Targeting: Lessons from Four Countries", Federal Reserve Bank of New York, Economic Policy Review, August 1997.

Mishkin Frederic S., and Klaus Schmidt-Hebbel "One Decade of Inflation Targeting in the World: What Do We Know and What Do We Need to Know", NBER working paper 8397, July 2001.

Svensson Lars, E.O., The Swedish Experience of an Inflation Target, NBER working paper 4985, January 1995

\section{Copyrights}

Copyright for this article is retained by the author(s), with first publication rights granted to the journal. This is an open-access article distributed under the terms and conditions of the Creative Commons Attribution license (http://creativecommons.org/licenses/by/4.0/). 